MINERALOGIA, 45, No 3-4: 99-120 (2014)

DE DE GRUYTER OPEN

\title{
Petrogenesis of kyanite-quartz segregations in mica schists of the Western Tatra Mountains (Slovakia)
}

\author{
Paulina PYKA ${ }^{1 *}$, Aleksandra GAWĘDA ${ }^{1}$, Krzysztof SZOPA $^{1}$, Axel MÜLLER ${ }^{2}$, \\ Magdalena SIKORSKA ${ }^{3}$ \\ ${ }^{1}$ University of Silesia, Faculty of Earth Sciences, ul. Będzińska 60, 41-200 Sonowiec, Poland \\ ${ }^{2}$ Geological Survey of Norway (NGU), Leiv Eirikssons vei 39, 7040 Trondheim, Norway \\ ${ }^{3}$ Polish Geological Institute, Rakowiecka 4, Warsaw, Poland \\ *Corresponding author e-mail: paulina.pyka@vp.pl
}

Received: March 3, 2015

Received in revised form: September 15, 2015

Accepted: September 17, 2015

Available online: October 10, 2015

\begin{abstract}
In the Tatra Mountains (Slovakia) metamorphic complex, kyanite-quartz segregations with biotite-rich selvage occur in mylonitized mica schists. In this paper, the problem of fluid flow and aluminium mobility during the uplift of the crystalline massif, and the position of the segregations in the history of Western Tatra metamorphic complex, is adressed. The reaction Alm $+\mathrm{Rt} \rightarrow \mathrm{Ilm}+\mathrm{Ky}+\mathrm{Qtz}$ is considered to be the result of a pressure drop from above to below $9 \mathrm{kbar}$. Ti-in-biotite geothermometry shows the temperature range to be 579 $639^{\circ} \mathrm{C}$ that is related to heating and decompression associated with granite intrusion. Major-element mass-balance calculations show that $\mathrm{Al}$ remained stable in the selvage + segregation system whereas other elements (e.g. Cr, HFSE) were mobilized. The kyanite-quartz segregations formed from local fluids generated during dehydration of the metapelitic rocks during uplift. The main mechanism was likely diffusion-driven mass-transfer into extensionrelated cracks.
\end{abstract}

Key-words: kyanite-quartz segregation, aluminium mobilization, mass-balance, Tatra Mountains

\section{Introduction}

Kyanite, one of the polymorphic varieties of $\mathrm{Al}_{2} \mathrm{SiO}_{5}$, is an excellent marker of mediumto high-pressure metamorphism in metasedimentary rocks. However, specific vein- and lens-shaped segregations of $\mathrm{Al}_{2} \mathrm{SiO}_{5}$ polymorphs with quartz occur in many places in 
metapelitic rocks showing Barrowian metamorphism (Allaz et al. 2005; Ague 2011). Their presence is usually interpreted as due to $\mathrm{SiO}_{2}$ and $\mathrm{Al}_{2} \mathrm{O}_{3}$ mobilization and crystallization from channelized fluid exsolved during metamorphism (Ague 2011). Kyanite segregations have also been described from eclogites and interpreted as a result of local segregation phenomena (Widmer, Thompson 2001; Moussallam et al. 2012). These segregations may reflect (a) external fluid infiltration with advection of dissolved material, (b) single-pass or multi-pass infiltration of external fluids recycled by convection, (c) deformation-enhanced addition of advective material from a local fluid and/or (d) diffusion through stagnant fluid steered by a chemical gradient between vein and enclosing rocks (Widmer, Thompson 2001 and references therein).

In the Tatra Mountains metamorphic complex, megacrystic kyanite-quartz segregations occur within the mylonitized mica-schists on the SW-slope of Baranèc Mt. in Slovakia (Pyka et al. 2013a, b). The aim of the current paper is to discuss the problem of fluid flow and aluminium mobility during the uplift of the crystalline massif and the position of the kyanite-quartz segregations in the history of the Western Tatra metamorphic complex.

\section{Geological setting and sampling}

The Tatra Mountains crystalline basement is one of several core-mountains showing Variscan consolidation among the Mesozoic and Cenozoic sedimentary rocks of the Alpine chain of the Carpathians (Fig. 1a). The predominant part of the Tatra Mountains is formed by a polygenic Variscan granitoid intrusion (Gawęda, Szopa 2011; Burda et al. 2011; Burda et al. 2013). The metamorphic envelope of the intrusion is preserved mostly in the western part of the massif - the Western Tatra Mountains (Fig. 1b) and locally, as xenolithes, inside the granitoid intrusion (Gawęda 2009). In the metamorphic envelope, crystalline nappes were formed as a result of the Variscan collision and metamorphism, and partial melting of the accretionary prism occurred. The nappes are built of rocks of different lithologies (metapelites-metapsammites and metabasalts) and differing metamorphic grade, divided by the local shear zones (Gawęda, Burda 2004; Burda, Gawęda 2009; Moussalam et al. 2012; Deditius 2004). Their presence is linked to the closure of the Rheic Ocean (Gawęda, Golonka 2011).

On Baranièc Mt., two metamorphic nappes (units) bordered by the so called Baranièc overthrust have been defined (Gorek 1956; Gorek 1969; Fig. 1b, 2). The Upper Unit shows the higher metamorphic grade whereas the Lower Unit is characterised by a lower metamorphic grade: together, they define an inverted metamorphic zonation (Kohút, Janak 1994; Moussalam et al. 2012). Similar field relations have been described from the northern part of the metamorphic complex where metamorphic conditions in the Upper Unit estimated at $670-780^{\circ} \mathrm{C}$ and $7.5-9 \mathrm{kbar}$, resulted in partial melting and migmatization (Gawęda, Kozłowski 1998; Burda, Gawęda 2009). In the Lower Unit, composed of metapelites (gneisses and mica schists) representing a metaflysch sequence, metamorphic conditions have been estimated at $540-580^{\circ} \mathrm{C}$ and 5-8 kbar (Gawęda, Kozłowski 1998).

Megacrystic kyanite crystals, from 3 to $12 \mathrm{~cm}$ long (Fig. 3a) and showing the typical blue colour, are the main components of lens-like in shape kyanite-quartz segregations $<20 \mathrm{~cm}$ thick. The segregtios are located in cracks and pressure shadows in the strongly mylonitized mica schists on the south-western slope of Baranèc Mt. (Pyka et al. 2013b). 
The segregations were sampled (Ky1 and Ky2) from the slope above Holy Vrch, in the SE part of Baranèc Mt. (Fig. 2).

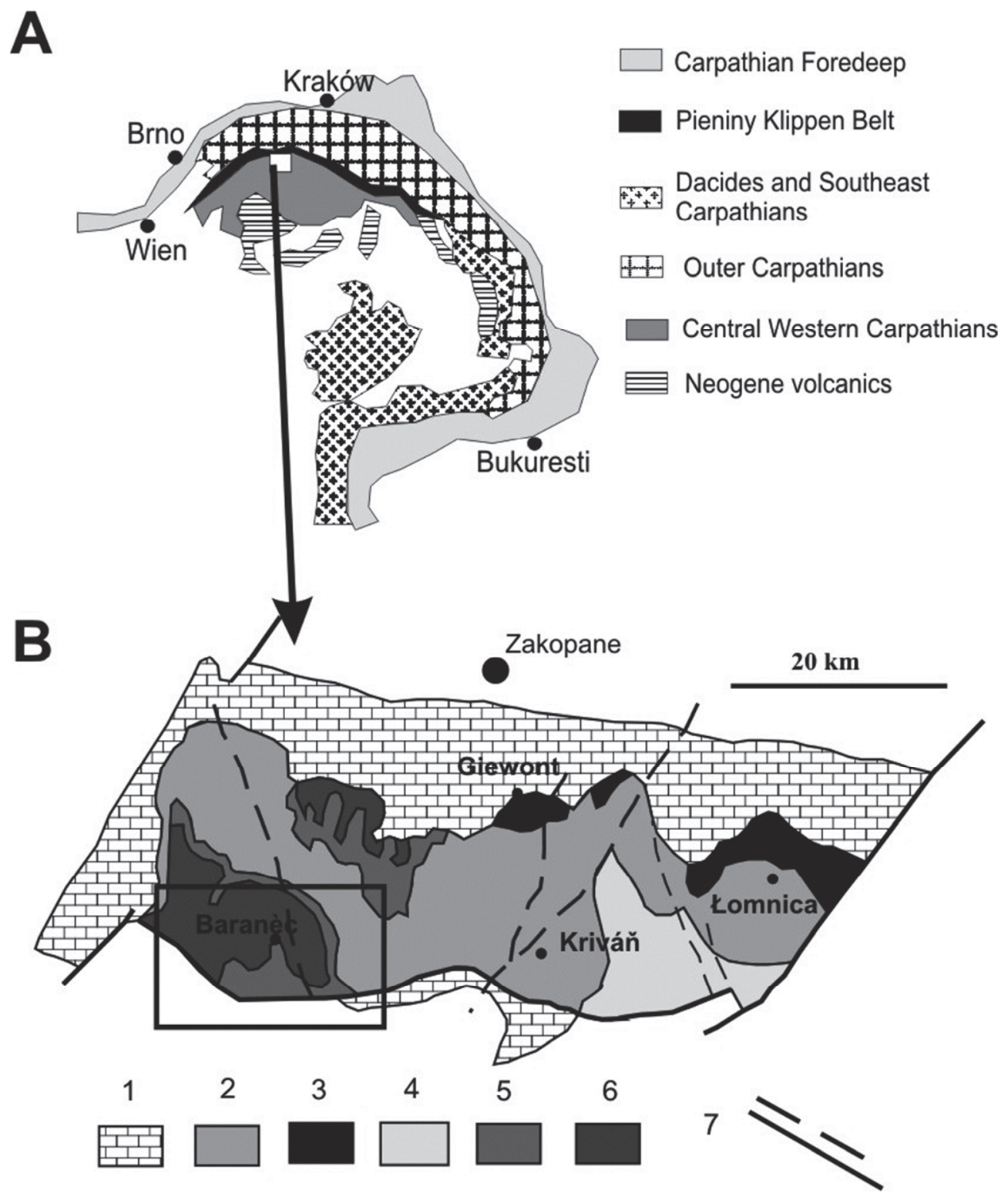

Fig. 1. General geological sketch of the Carpathian Belt (A) and a general geological map of the Tatra Mountains (B) - compilation from Gawęda (2009) and Moussalam et al. (2012).

1- Mesozoic sediments, 2 - common Tatra granite, 3 - Goryczkowa type granite, 4 - High Tatra type granite, 5 - metamorphic rocks of Upper Unit, 6 - metamorphic rocks of Lower Unit, 7- faults identified $\&$ assumed. 


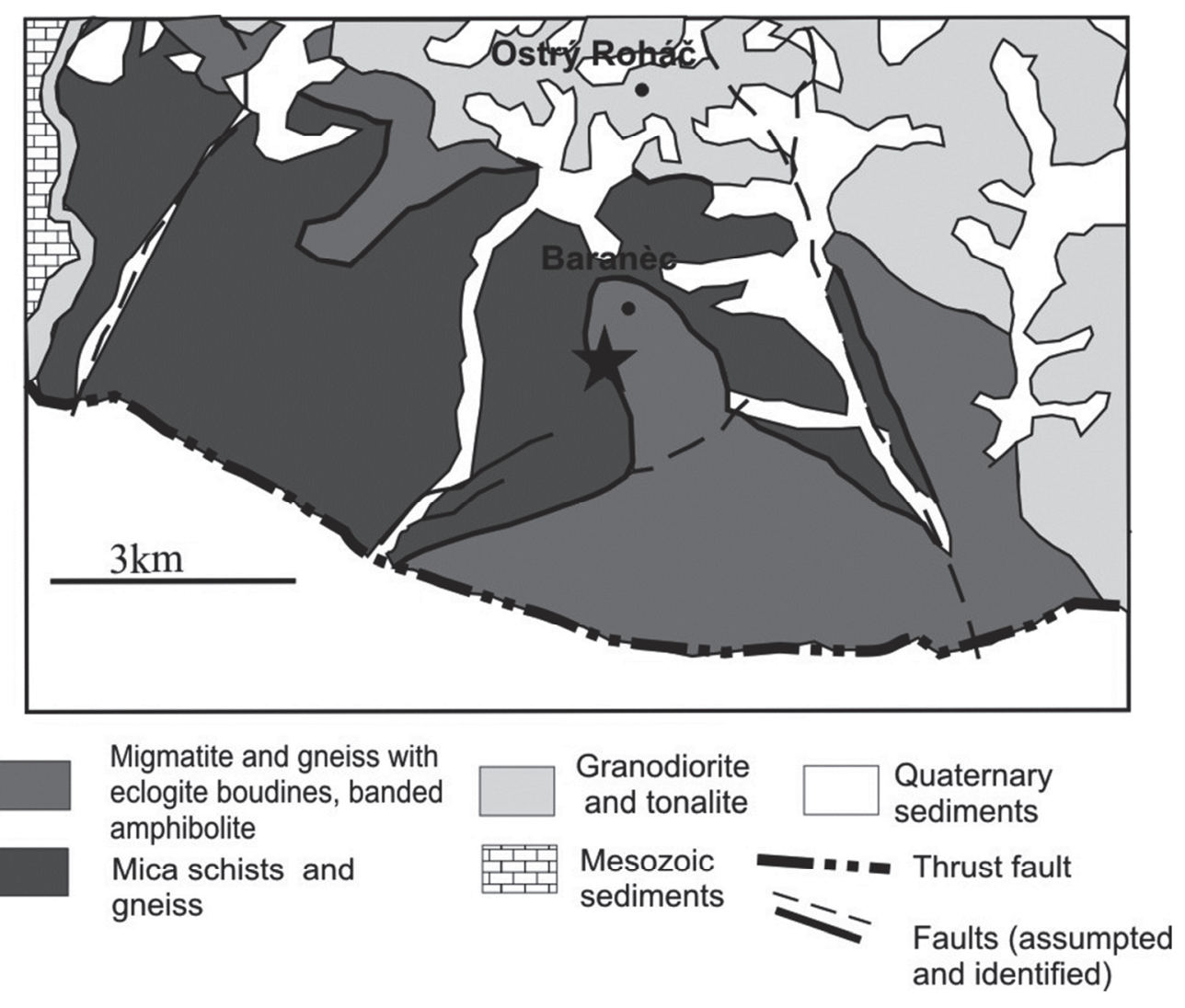

Fig. 2. General geological map of the study area (rectangle on Fig. 1). Star - sampling location. Map after Moussalam et al. (2012).

\section{Analytical methods}

Microscopic observations using an OLIMPUS BX-51 microscope (Faculty of Earth Sciences, University of Silesia) were followed by cathodoluminescence imaging using a CCL 8200 mk3 apparatus (Cambridge Image Technology Ltd.) mounted on an Optiphot 2 Nikon microscope (Polish Geological Institute, Warsaw). The applied accelerating voltage was $20 \mathrm{kV}$, the beam current $500 \mathrm{~mA}$ and the vacuum 0.5-0.2 Torr.

Electron probe micro analyses (EPMA) of major elements were done in the InterInstitutional laboratory of Microanalyses of Minerals and Synthetic Substances, Warsaw, using a Cameca SX-100 electron microprobe. The analytical conditions were: acceleration voltage $15 \mathrm{kV}$, beam current $10 \mathrm{nA}$, counting time $4 \mathrm{~s}$ for peak and background, beam diameter 1-5 $\mu \mathrm{m}$. Natural- and synthetic standards used were wollastonite for $\mathrm{Si}$ and $\mathrm{Ca}$, orthoclase for $\mathrm{Al}$ and $\mathrm{K}$, diopside for $\mathrm{Mg}$, rhodonite for $\mathrm{Mn}$ and synthetic hematite for Fe. Trace elements were analysed by laser ablation inductively coupled plasma mass spectrometry (LA-ICP-MS) in the Geological Survey of Norway, Trondheim, using a double focusing sector field instrument (model-ELEMENT-1, Finnigan MAT) combined 
with a New Wave UP-193 nm excimer laser probe. Continuous raster ablation was carried out using a repetition rate of $10 \mathrm{~Hz}$, a spot size of $50 \mu \mathrm{m}$, a laser speed of $10 \mu \mathrm{m} / \mathrm{s}$ and pulse energy of $16.4 \mathrm{~mJ}$. LA-ICP-MS was used for the in-situ determination of $\mathrm{Na}^{23}, \mathrm{Mg}^{24}, \mathrm{~K}^{39}$, $\mathrm{Ca}^{44}, \mathrm{Ti}^{47}, \mathrm{~V}^{51}, \mathrm{Cr}^{52}, \mathrm{Mn}^{55}$ and $\mathrm{Fe}^{56}$ in the kyanite.

$\mathrm{X}$-ray powder diffraction data of separated kyanite crystals were collected at the Faculty of Earth Sciences, University of Silesia, using a PW3040/60 diffractometer ( $\mathrm{CoK}_{\alpha 1}$ radiation, $45 \mathrm{kV}, 30 \mathrm{~mA}$, scan range $2.5-65^{\circ} 2 \Theta$, step size $0.01^{\circ} 2 \Theta$, scan step time $300 \mathrm{~s}$ ). Structural data were obtained using XPERT High Score + software and the standard data base ICDD PDF4+ 2012.

Bulk chemical compositions were analyzed by X-ray fluorescence (XRF; major elements and LILE), in combination with inductively coupled plasma-emission spectrometry and mass spectrometry (ICP-ES and ICP-MS; HFS elements) by ACME Analytical Laboratories, Vancouver, Canada. Preparation involved lithium borate fusion and dilute digestions or hot four-acid digestion for ICP-ES, $\mathrm{LiBO}_{2}$ fusion for XRF and lithium borate decomposition or aqua regia digestion for ICP-MS. LOI was determined at $1000^{\circ} \mathrm{C}$.

\section{Results}

\subsection{Petrography and mineral chemistry}

The kyanite-quartz segregations occur in mylonitized micaschists. The schists are composed of quartz, muscovite, biotite, garnet and plagioclase. Foliation is defined by the alignment of muscovite and biotite.

The segregations are composed of kyanite, quartz, fibrolitic silimanite and muscovite with accessory plagioclase, apatite with inclusions of garnet, biotite and rutile. The segregations are bordered by selvages of biotite, fibrolitic silimanite, feldspar, relict kyanite, accessory ilmenite, rutile and apatite. Chlorite and muscovite are secondary. Two mineral parageneses can be distinguished: (I) Rt-Grt $1-\mathrm{Ky}_{-}-\mathrm{Bt}_{1}$ and (II) Ilm-Grt 2 -Sil$\mathrm{Bt}_{2}(-\mathrm{Ms})$.

\subsubsection{Kyanite-quartz segregations}

The main components of the segregations are isomorphic- to sub-idiomorphic bluish kyanite crystals (Fig. 3a) characterized by almost ideal crystal-chemical formulae with only small Fe substitutions (Table 1). The kyanite crystals are replaced by fibrolitic sillimanite that mantles kyanite aggregates (Fig. 3c, 4b). Thin sections reveal the presence of muscovite $\left(\mathrm{Ms}_{1}\right)$ replacing the kyanite and sillimanite, both from outer rims and along cleavages (Fig. 3c). Microchemical analyses indicate Tschermak substitution $\left(\mathrm{Al}^{\mathrm{IV}} \mathrm{Al}^{\mathrm{VI}} \leftrightarrow\right.$ $\left.\mathrm{Si}^{\mathrm{IV}} \mathrm{Mg}^{\mathrm{VI}}\right)$ in the muscovite $\left(\mathrm{Ms}_{1}\right)$ and $\mathrm{Fe}$ and $\mathrm{Ti}$ enrichment $(0.112-0.442$ a.p.f.u. $\mathrm{Fe}$ and $<0.102$ a.p.f.u. Ti; Table 2). Xenomorphic quartz shows undulose extinction. Accessory plagioclase (oligoclase-albite) is represented by subhedral, normally zoned crystals $\left(\mathrm{Ab}_{86} \mathrm{An}_{11} \mathrm{Or}_{3}-\mathrm{Ab}_{78} \mathrm{An}_{21} \mathrm{Or}_{1}\right.$ in cores to $\mathrm{Ab}_{99} \mathrm{Or}_{1}-\mathrm{Ab}_{97} \mathrm{Or}_{3}$ at rims) up to $200 \mu \mathrm{m}$ in size. Inclusions of apatite-(Ca,F), $<300 \mu \mathrm{m}$ in size occur in kyanite; in both apatite and host kyanite, inclusions of idiomorphic garnet, biotite and rutile are found $(<10 \mu \mathrm{m}$ in size; Fig. 
4a, 5a, b). Garnet $\left(\mathrm{Grt}_{1}\right)$ is almandine-spessartine ( $\mathrm{Alm}_{63} \mathrm{Spes}_{18} \mathrm{Py}_{6} \mathrm{Gros}_{10} \mathrm{Andr}_{3}$ $\mathrm{Alm}_{68} \mathrm{Spes}_{16} \mathrm{Py}_{8} \mathrm{Gros}_{5} \mathrm{Andr}_{3}$; Table 3). Biotite $\left(\mathrm{Bt}_{1}\right)$ is characterized by $\mathrm{Fe} /(\mathrm{Fe}+\mathrm{Mg}+\mathrm{Mn})$, i.e. $\# f m$ in the range of $0.544-0.553$ and $\mathrm{Ti}=0.215-0.232$ a.p.f.u. (Table 4). Rutile inclusions $(<50 \mu \mathrm{m})$ are usually idiomorphic (Fig. 5).
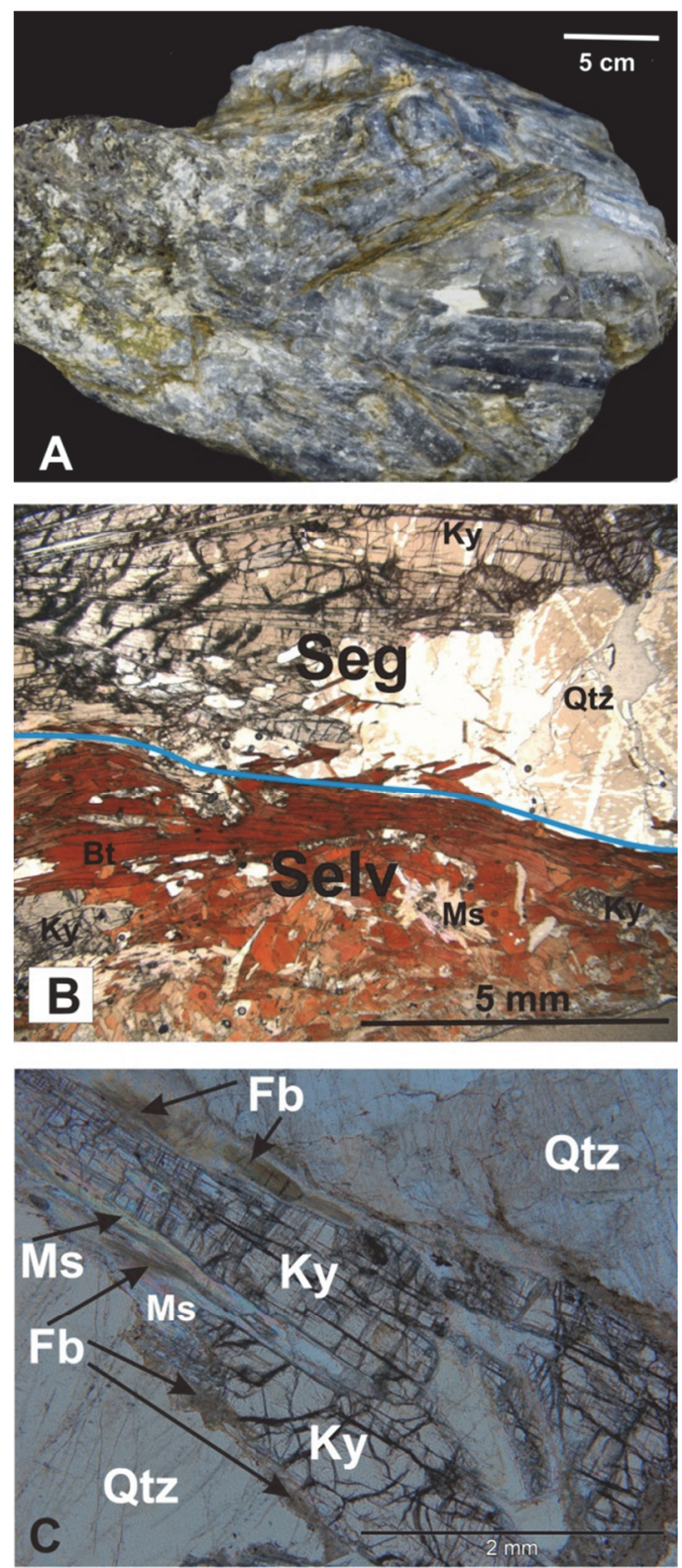

Fig. 3. Microphotographs of kyanite-quartz segregations. A. Kyanite crystals $<12 \mathrm{~cm}$ long. B. Kyanite-quartz segregation (Seg) bordered by biotite-rich selvage (Selv). C. Kyanite crystals (Ky) overgrown by muscovite (Ms) and fibrolite (Fb), all wrapped by quartz (Qtz). 
Chemical composition (wt\%) and crystal-chemical formulae of kyanite.

\begin{tabular}{|c|c|c|c|c|c|c|c|c|c|c|}
\hline Sample & LoD & Ky_1 & Ky_2 & Ky_3 & Ky_4 & Ky_5 & Ky_6 & Ky_7 & Ky_8 & Ky_9 \\
\hline $\mathrm{SiO}_{2}$ & 0.03 & 37.24 & 37.15 & 37.28 & 37.01 & 37.02 & 37.27 & 37.35 & 37.53 & 37.27 \\
\hline $\mathrm{Al}_{2} \mathrm{O}_{3}$ & 0.03 & 63.34 & 62.74 & 62.66 & 62.58 & 63.09 & 63.00 & 62.88 & 62.95 & 62.56 \\
\hline $\mathrm{FeO}$ & 0.15 & - & - & - & 0.20 & 0.21 & - & - & - & 0.27 \\
\hline Total & & 100.58 & 99.89 & 99.94 & 99.79 & 100.32 & 100.27 & 100.23 & 100.48 & 100.11 \\
\hline \multicolumn{11}{|c|}{ crystal-chemical formulae recalculated to $20 \mathrm{O}^{2-}$} \\
\hline $\mathrm{Si}$ & & 3.990 & 4.01 & 4.017 & 4.004 & 3.985 & 4.007 & 4.019 & 4.021 & 4.020 \\
\hline $\mathrm{Al}^{\mathrm{IV}}$ & & 4.010 & 3.990 & 3.983 & 3.996 & 4.015 & 3.993 & 3.981 & 3.979 & 3.980 \\
\hline $\mathrm{Al}^{\mathrm{VI}}$ & & 3.988 & 3.991 & 3.973 & 3.983 & 3.989 & 3.991 & 3.994 & 3.971 & 3.973 \\
\hline $\mathrm{Fe}^{2+}$ & & - & - & - & 0.018 & 0.019 & - & - & - & 0.024 \\
\hline
\end{tabular}
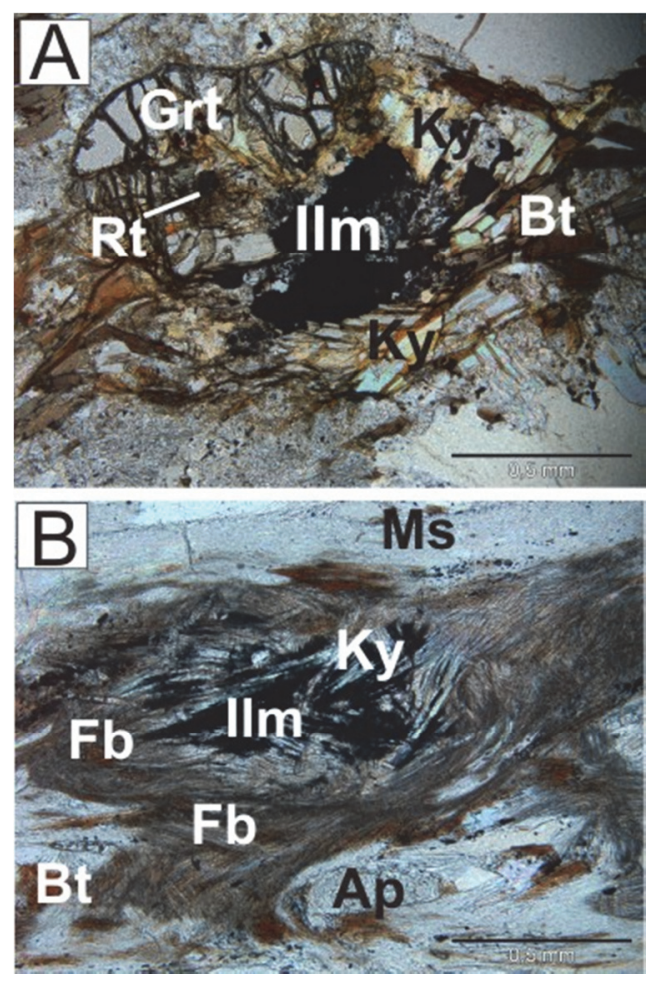

Fig. 4. Microphotographs showing phase relations. A. Kyanite (Ky) and ilmenite (Ilm) growing at the expense of almandine-garnet (Grt) and rutile (Rt). Biotite (Bt) also present. B. Ilmenite (Ilm) and kyanite $(\mathrm{Ky})$ bordered by fibrolite $(\mathrm{Fb})$ and muscovite $(\mathrm{Ms})$. Biotite $(\mathrm{Bt})$ and accessory apatite (Ap) also present. 
TABLE 2

Chemical composition (wt $\%$ ) and crystal-chemical formulae of muscovite $\mathrm{Ms}_{1}$ in the kyanite-quartz segregations and muscovite $\mathrm{Ms}_{2}$ in the selvage.

\begin{tabular}{|c|c|c|c|c|c|c|c|c|c|c|}
\hline \multirow[t]{2}{*}{ Sample } & \multicolumn{6}{|c|}{ Muscovite 1} & \multicolumn{4}{|c|}{ Muscovite 2} \\
\hline & LoD & Ms1_1 & Ms1_2 & Ms1_3 & Ms1_4 & Ms1_5 & Ms2_1 & Ms2_2 & Ms2_3 & Ms2_4 \\
\hline $\mathrm{SiO}_{2}$ & 0.03 & 46.06 & 46.80 & 47.72 & 45.85 & 46.12 & 46.73 & 46.77 & 47.58 & 46.77 \\
\hline $\mathrm{TiO}_{2}$ & 0.05 & 0.35 & 0.37 & 0.40 & 0.33 & 1.02 & - & - & - & - \\
\hline $\mathrm{Al}_{2} \mathrm{O}_{3}$ & 0.03 & 30.31 & 31.25 & 31.10 & 36.81 & 36.03 & 36.84 & 36.60 & 35.58 & 37.17 \\
\hline $\mathrm{MgO}$ & 0.02 & 2.94 & 2.41 & 2.72 & 0.59 & - & 0.40 & 0.39 & 0.74 & 0.37 \\
\hline $\mathrm{FeO}$ & 0.16 & 3.86 & 2.80 & 2.01 & 1.11 & 0.57 & 0.63 & 0.46 & 0.61 & 0.54 \\
\hline $\mathrm{Na}_{2} \mathrm{O}$ & 0.03 & 0.08 & 0.16 & 0.27 & 1.19 & 1.04 & 1.46 & 1.27 & 0.77 & 1.53 \\
\hline $\mathrm{K}_{2} \mathrm{O}$ & 0.06 & 10.54 & 10.67 & 10.46 & 9.52 & 9.87 & 9.55 & 9.38 & 9.78 & 9.33 \\
\hline $\mathrm{H}_{2} \mathrm{O}_{\text {calc }}$ & & 4.38 & 4.43 & 4.46 & 4.54 & 4.55 & 4.56 & 4.54 & 4.55 & 4.58 \\
\hline Total & & 98.52 & 98.87 & 99.14 & 99.93 & 100.08 & 100.17 & 99.40 & 99.62 & 100.29 \\
\hline \multicolumn{11}{|c|}{ crystal-chemical formulae recalculated to $22 \mathrm{O}^{2-}$} \\
\hline $\mathrm{Si}$ & & 6.305 & 6.339 & 6.412 & 6.06 & 6.086 & 6.148 & 6.178 & 6.272 & 6.128 \\
\hline $\mathrm{Ti}$ & & 0.036 & 0.037 & 0.04 & 0.033 & 0.102 & - & - & - & - \\
\hline $\mathrm{Al}^{\mathrm{IV}}$ & & 1.695 & 1.661 & 1.588 & 1.94 & 1.914 & 1.852 & 1.822 & 1.728 & 1.872 \\
\hline $\mathrm{Al}^{\mathrm{VI}}$ & & 3.195 & 3.327 & 3.336 & 3.794 & 3.689 & 3.859 & 3.876 & 3.800 & 3.869 \\
\hline $\mathrm{Mg}$ & & 0.600 & 0.486 & 0.545 & 0.116 & - & 0.078 & 0.077 & 0.146 & 0.073 \\
\hline $\mathrm{Fe}$ & & 0.442 & 0.317 & 0.226 & 0.122 & 0.112 & 0.069 & 0.051 & 0.068 & 0.059 \\
\hline $\mathrm{Na}$ & & 0.022 & 0.041 & 0.07 & 0.306 & 0.265 & 0.372 & 0.326 & 0.196 & 0.389 \\
\hline $\mathrm{K}$ & & 1.841 & 1.844 & 1.792 & 1.604 & 1.661 & 1.603 & 1.581 & 1.645 & 1.560 \\
\hline
\end{tabular}

\subsubsection{Selvages}

Selvages bordering the kyanite-quartz segregations (Fig. 3b) are composed of biotite $\left(\mathrm{Bt}_{2}: \# f m=0.506-0.551 ; \mathrm{Ti}=0.192-0.272\right.$ a.p.f.u.; Table 4), plagioclase and fibrolitic sillimatite, and porphyroblasts of almandine garnet $\left(\mathrm{Grt}_{2}: \mathrm{Alm}_{74} \mathrm{Spes}_{5} \mathrm{Py}_{7} \mathrm{Gros}_{14}\right.$ $\mathrm{Alm}_{74} \mathrm{Spes}_{7} \mathrm{Py}_{15} \mathrm{Gros}_{3}$; Table 3). Locally, kyanite crystals, $<0.5 \mathrm{~mm}$ in length, are associated with ilmenite that is partially replaced by sillimanite and muscovite (Fig. 4a, b).

Accessories are represented by K-feldspar $\left(\mathrm{Or}_{76} \mathrm{Ab}_{24}-\mathrm{Or}_{97} \mathrm{Ab}_{3}\right)$, ilmenite with $\mathrm{Mn}$ substitution in the range of 0.30-0.33 a.p.f.u (Table 5), $(\mathrm{Ca}, \mathrm{F})$-apatite with $<0.23 \mathrm{wt} \% \mathrm{Y}_{2} \mathrm{O}_{3}$ and $<0.24 \mathrm{wt} \% \mathrm{MnO}$, and rutile. 

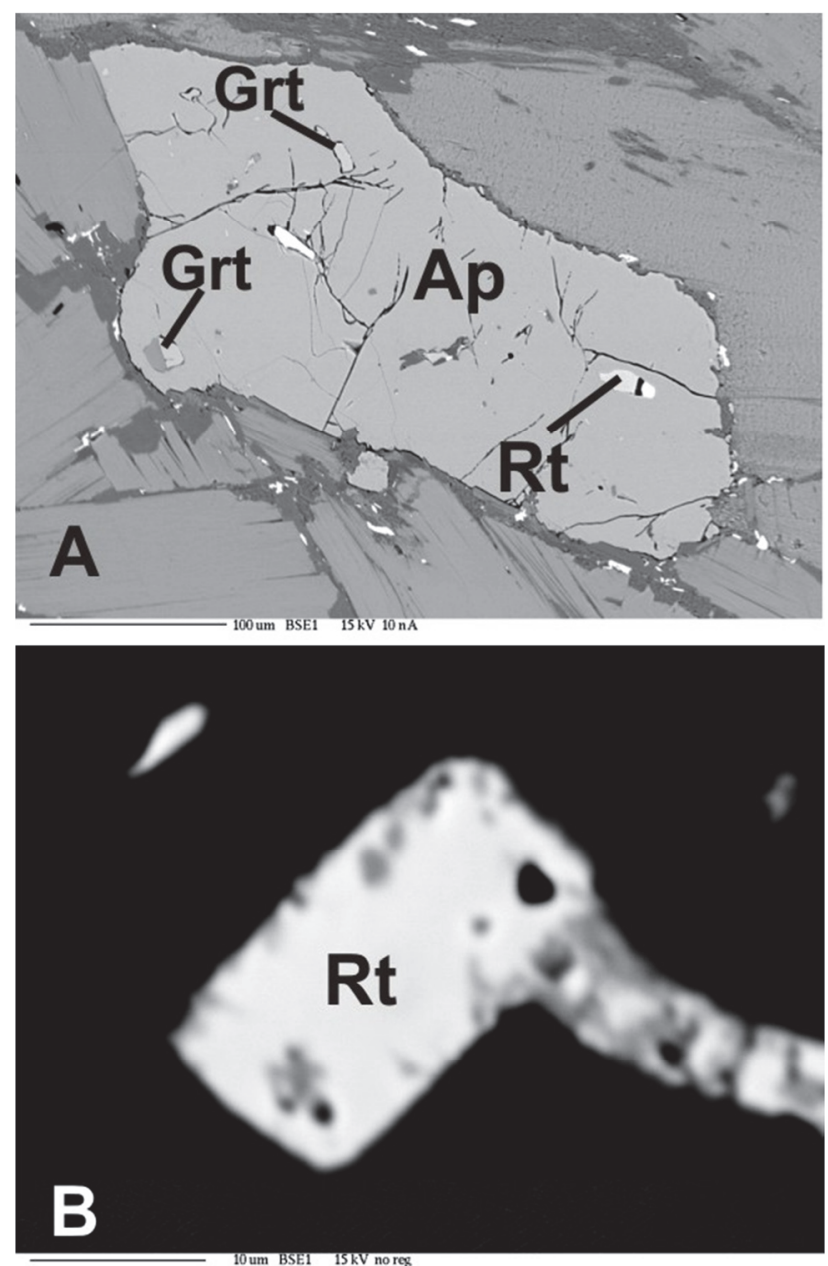

Fig. 5. A. Apatite (Ap) with garnet (Grt) and rutile (Rt) inclusions. B. Rutile crystal. (BSE images).

Secondary muscovite $\left(\mathrm{Ms}_{2}\right)$ replacing the $\mathrm{Al}_{2} \mathrm{SiO}_{5}$ polymorphs (Fig. 3c, 4b) shows a simple chemical composition (Table 2). Secondary chlorite replacing biotite along cleavage planes is $(\mathrm{Mg}, \mathrm{Fe})$-chlorite from the groups of ripidolite, picnochlorite and diabantine $(\# f m=0.485-0.785)$. 
TABLE 3

Chemical composition (wt\%) and crystal-chemical formulae of garnet $\mathrm{Grt}_{1}$ from apatite inclusions and $\mathrm{Grt}_{2}$ present as porphyroblasts in the selvage.

* Analyses used for geothermometry. Values of $\mathrm{Fe}^{3+}$ and $\mathrm{Fe}^{2+}$ are result of microprobe analyses.

\begin{tabular}{|c|c|c|c|c|c|c|c|c|c|c|}
\hline Sample & Grt1 & & & Grt2 & & & & & & \\
\hline & LoD & *Grt1_1 & *Grt1_2 & Grt2_1 & Grt2_2 & Grt2_3 & Grt2_4 & Grt2_5 & Grt2_6 & Grt2_7 \\
\hline $\mathrm{SiO}_{2}$ & 0.01 & 35.71 & 36.53 & 37.48 & 37.57 & 37.18 & 37.71 & 37.50 & 37.40 & 37.66 \\
\hline $\mathrm{Al}_{2} \mathrm{O}_{3}$ & 0.01 & 19.46 & 19.59 & 21.24 & 21.19 & 21.32 & 21.28 & 21.30 & 21.62 & 21.81 \\
\hline $\mathrm{Fe}_{2} \mathrm{O}_{3}$ & 0.07 & 1.64 & 1.60 & - & 0.08 & - & - & 0.04 & - & - \\
\hline $\mathrm{FeO}$ & 0.07 & 28.59 & 30.83 & 33.21 & 32.86 & 33.33 & 32.37 & 33.19 & 33.56 & 33.71 \\
\hline $\mathrm{CaO}$ & 0.02 & 3.53 & 1.70 & 4.91 & 5.12 & 5.02 & 5.04 & 4.98 & 1.16 & 1.12 \\
\hline $\mathrm{MnO}$ & 0.07 & 8.28 & 7.11 & 2.05 & 2.04 & 1.89 & 1.98 & 2.00 & 3.73 & 2.91 \\
\hline $\mathrm{MgO}$ & 0.01 & 1.50 & 1.97 & 1.91 & 2.06 & 2.17 & 2.02 & 2.13 & 3.15 & 3.91 \\
\hline Total & & 98.71 & 99.33 & 100.79 & 101.00 & 100.94 & 100.49 & 101.17 & 100.61 & 101.11 \\
\hline \multicolumn{11}{|c|}{ Formulae recalculated to $24 \mathrm{O}^{2-}$} \\
\hline $\mathrm{Si}$ & & 5.920 & 6.000 & 5.989 & 5.987 & 5.942 & 6.021 & 5.971 & 5.963 & 5.975 \\
\hline $\mathrm{Al}$ & & 3.800 & 3.790 & 4.001 & 3.98 & 4.014 & 4.004 & 3.997 & 4.069 & 4.071 \\
\hline $\mathrm{Fe}^{3+}$ & & 0.200 & 0.200 & - & 0.009 & - & - & 0.005 & - & - \\
\hline $\mathrm{Fe}^{2+}$ & & 3.970 & 4.230 & 4.438 & 4.379 & 4.455 & 4.322 & 4.42 & 4.464 & 4.484 \\
\hline $\mathrm{Ca}$ & & 0.630 & 0.300 & 0.841 & 0.874 & 0.86 & 0.861 & 0.85 & 0.189 & 0.199 \\
\hline $\mathrm{Mn}$ & & 1.160 & 1.000 & 0.277 & 0.275 & 0.256 & 0.267 & 0.27 & 0.39 & 0.504 \\
\hline $\mathrm{Mg}$ & & 0.370 & 0.480 & 0.456 & 0.49 & 0.517 & 0.48 & 0.505 & 0.924 & 0.751 \\
\hline $\mathrm{X}_{\mathrm{py}}$ & & 0.058 & 0.077 & 0.074 & 0.082 & 0.086 & 0.080 & 0.084 & 0.154 & 0.125 \\
\hline $\mathrm{X}_{\mathrm{alm}}$ & & 0.627 & 0.681 & 0.738 & 0.728 & 0.741 & 0.719 & 0.735 & 0.743 & 0.746 \\
\hline $\mathrm{X}_{\text {spes }}$ & & 0.183 & 0.161 & 0.046 & 0.046 & 0.042 & 0.044 & 0.045 & 0.065 & 0.084 \\
\hline$X_{\text {gross }}$ & & 0.099 & 0.048 & 0.140 & 0.145 & 0.143 & 0.143 & 0.141 & 0.031 & 0.033 \\
\hline $\mathrm{X}_{\mathrm{adr}}$ & & 0.032 & 0.032 & 0 & 0.001 & 0 & 0 & 0.001 & 0 & 0 \\
\hline $\mathrm{T}\left[{ }^{\circ} \mathrm{C}\right]_{\mathrm{FS}}$ & & 432.1 & 492.5 & - & - & - & - & - & - & - \\
\hline $\mathrm{T}\left[{ }^{\circ} \mathrm{C}\right]_{\mathrm{IM}}$ & & 506.6 & 529.8 & - & - & - & - & - & - & - \\
\hline
\end{tabular}


TABLE 4

Chemical composition (wt $\%$ ) and crystal-chemical formulae of biotite inclusions in the segregation $\left(\mathrm{Bt}_{1}\right)$ and from the selvage $\left(\mathrm{Bt}_{2}\right)$ with temperatures computed according to the Ti-in-Bt geotermometer of Henry et al. (2005).* Analyses used for geothermometry.

\begin{tabular}{|c|c|c|c|c|c|c|c|c|c|c|}
\hline & & Biotite 1 & & Biotite & & & & & & \\
\hline Sample & LoD & *Bt1_1 & *Bt1_2 & Bt2_1 & $\mathrm{Bt} 2 \_2$ & $\mathrm{Bt} 2 \_3$ & Bt2_4 & Bt2_5 & Bt2_6 & Bt2_7 \\
\hline $\mathrm{SiO}_{2}$ & 0.03 & 34.68 & 35.09 & 35.24 & 36.05 & 35.20 & 35.53 & 35.62 & 36.27 & 36.39 \\
\hline $\mathrm{TiO}_{2}$ & 0.06 & 2.01 & 1.88 & 2.38 & 2.01 & 2.06 & 2.11 & 1.98 & 1.70 & 1.78 \\
\hline $\mathrm{Al}_{2} \mathrm{O}_{3}$ & 0.02 & 19.91 & 20.20 & 19.24 & 18.90 & 18.89 & 19.15 & 19.11 & 21.70 & 21.72 \\
\hline $\mathrm{FeO}$ & 0.16 & 19.53 & 19.30 & 20.16 & 18.76 & 19.68 & 19.46 & 19.94 & 16.65 & 16.35 \\
\hline $\mathrm{MnO}$ & 0.17 & 0.22 & 0.19 & - & - & 0.19 & 0.22 & - & - & - \\
\hline $\mathrm{MgO}$ & 0.03 & 9.30 & 8.84 & 9.23 & 9.67 & 9.66 & 9.73 & 9.73 & 8.70 & 8.94 \\
\hline $\mathrm{Na}_{2} \mathrm{O}$ & 0.05 & 0.12 & 0.14 & 0.19 & 0.18 & 0.18 & 0.21 & 0.17 & 0.23 & 0.16 \\
\hline $\mathrm{K}_{2} \mathrm{O}$ & 0.03 & 8.96 & 8.89 & 9.06 & 8.95 & 8.90 & 8.97 & 9.08 & 9.19 & 9.35 \\
\hline $\mathrm{H}_{2} \mathrm{O}$ & & 3.92 & 3.93 & 3.95 & 3.95 & 3.92 & 3.96 & 3.96 & 4.00 & 4.01 \\
\hline Total & & 98.71 & 98.61 & 99.44 & 98.46 & 98.70 & 99.32 & 99.60 & 98.44 & 98.70 \\
\hline \multicolumn{11}{|c|}{ crystal-chemical formulae recalculated to $22 \mathrm{O}^{2-}$} \\
\hline $\mathrm{Si}$ & & 5.304 & 5.356 & 5.353 & 5.476 & 5.379 & 5.382 & 5.39 & 5.441 & 5.441 \\
\hline $\mathrm{Ti}$ & & 0.232 & 0.215 & 0.272 & 0.229 & 0.237 & 0.24 & 0.225 & 0.192 & 0.201 \\
\hline $\mathrm{Al}^{\mathrm{IV}}$ & & 2.696 & 2.644 & 2.647 & 2.524 & 2.621 & 2.618 & 2.61 & 2.559 & 2.559 \\
\hline $\mathrm{Al}^{\mathrm{VI}}$ & & 0.893 & 0.991 & 0.798 & 0.861 & 0.782 & 0.8 & 0.798 & 1.278 & 1.268 \\
\hline $\mathrm{Fe}^{2+}$ & & 2.498 & 2.464 & 2.562 & 2.383 & 2.515 & 2.465 & 2.524 & 2.089 & 2.045 \\
\hline $\mathrm{Mn}$ & & 0.029 & 0.024 & - & - & 0.025 & 0.028 & - & - & - \\
\hline $\mathrm{Mg}$ & & 2.120 & 2.011 & 2.09 & 2.191 & 2.201 & 2.198 & 2.194 & 1.946 & 1.993 \\
\hline $\mathrm{Na}$ & & 0.037 & 0.042 & 0.055 & 0.052 & 0.053 & 0.06 & 0.051 & 0.068 & 0.045 \\
\hline $\mathrm{K}$ & & 1.748 & 1.731 & 1.756 & 1.735 & 1.735 & 1.734 & 1.753 & 1.758 & 1.784 \\
\hline $\mathrm{fm}$ & & 0.544 & 0.553 & 0.551 & 0.523 & 0.536 & 0.531 & 0.536 & 0.518 & 0.506 \\
\hline$X_{\mathrm{Mg}}$ & & 0.367 & 0.352 & 0.365 & 0.385 & 0.382 & 0.383 & 0.381 & 0.353 & 0.362 \\
\hline $\mathrm{X}_{\mathrm{Fe}}$ & & 0.433 & 0.432 & 0.448 & 0.419 & 0.437 & 0.430 & 0.439 & 0.379 & 0.371 \\
\hline $\mathrm{X}_{\mathrm{Ti}}$ & & 0.040 & 0.038 & 0.047 & 0.040 & 0.041 & 0.042 & 0.039 & 0.035 & 0.036 \\
\hline $\mathrm{T}\left[{ }^{\circ} \mathrm{C}\right]$ & & & & 638.8 & 613.5 & 617.3 & 620.6 & 607.0 & 578.8 & 591.3 \\
\hline
\end{tabular}


Chemical composition (wt $\%$ ) and crystal-chemical formulae of ilmenite.

\begin{tabular}{|c|c|c|c|c|c|c|c|}
\hline Sample & LoD & Ilm_1 & $\mathrm{Ilm} \_2$ & Ilm_3 & $\mathrm{Ilm}_{-} 4$ & $\operatorname{Ilm} \_5$ & Ilm_6 \\
\hline $\mathrm{TiO}_{2}$ & 0.03 & 53.89 & 54.30 & 54.07 & 53.49 & 56.36 & 54.30 \\
\hline $\mathrm{FeO}$ & 0.07 & 38.09 & 37.44 & 38.71 & 38.35 & 33.64 & 34.01 \\
\hline $\mathrm{MnO}$ & 0.07 & 7.59 & 7.14 & 7.02 & 7.74 & 7.18 & 8.74 \\
\hline Total & & 99.57 & 98.88 & 99.80 & 99.58 & 97.46 & 97.89 \\
\hline \multicolumn{8}{|c|}{ crystal-chemical formulae recalculated to $6 \mathrm{O}^{2-}$} \\
\hline $\mathrm{Ti}$ & & 2.03 & 2.06 & 2.04 & 2.02 & 2.128 & 2.057 \\
\hline $\mathrm{Fe}$ & & 1.6 & 1.58 & 1.62 & 1.61 & 1.412 & 1.433 \\
\hline $\mathrm{Mn}$ & & 0.32 & 0.3 & 0.3 & 0.33 & 0.305 & 0.373 \\
\hline
\end{tabular}

LoD - limits of detection.

\subsubsection{Phase relations and geothermometry}

The assemblage rutile + almandine garnet occurs as inclusions in apatite (Fig. 5a) and kyanite. In the host metapelites, kyanite and ilmenite growing at the expence of garnet and rutile are observed (Fig. 4a) while, in the selvage, complete pseudomorphs after garnet + rutile are evident (Fig. 4b). In the kyanite-quartz segregations, rutile and garnet are

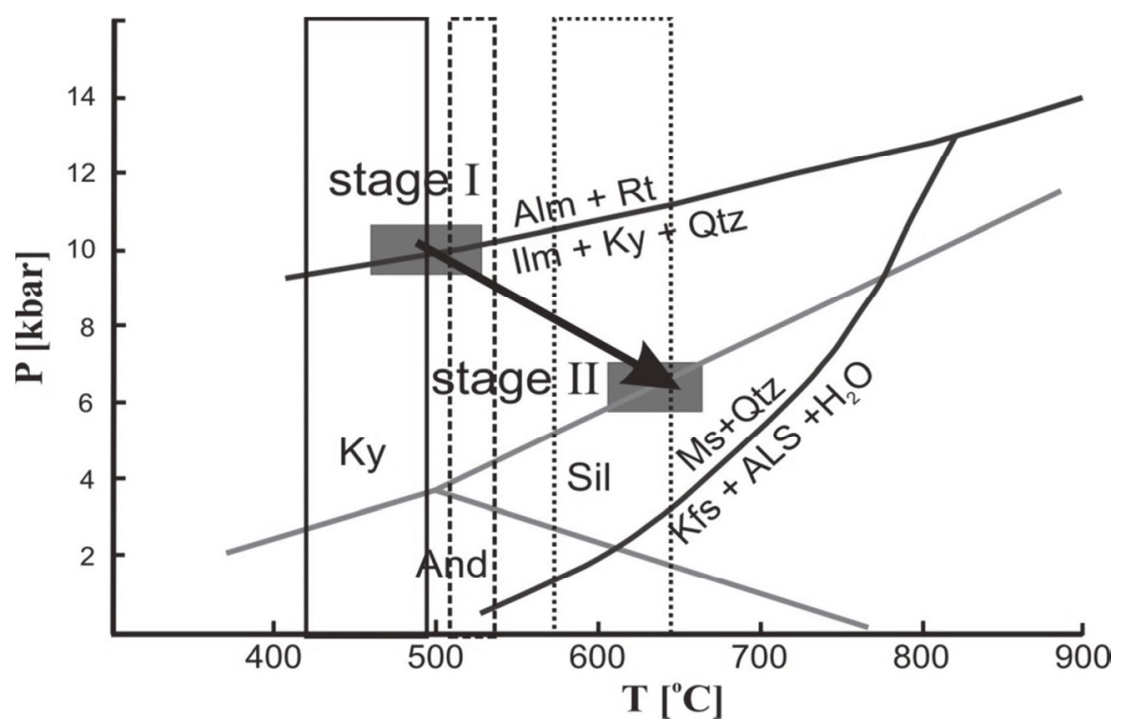

Fig. 6. P-T path of the kyanite-quartz segregation formation: solid line - Grt-Bt geothermometry by Ferry and Spear (1978), dashed line - Grt-Bt geothermometry by Indares and Martignole (1985), dotted line - Ti-in-Bt geothermometry by Henry et al. (2005). Stage I (higher pressure (above 9 kbar) - formation of the kyanite-quartz segregations; Stage II (pressure dropped to 5-4 kbars and shifted to higher temperatures) - connected with uplift and granitoid intrusion. 
preserved only as inclusions in apatite and in kyanite. Garnet $\mathrm{Grt}_{1}$ and biotite $\mathrm{Bt}_{1}$ inclusions are in chemical balance and were used to estimate the temperature (Table 3 and 4). The method of Ferry and Spear (1978) gives temperatures in the range $432-492^{\circ} \mathrm{C}$ whereas the calibration by Indares and Martignole (1985) yields temperatures in the range $507-530^{\circ} \mathrm{C}$ (Fig. 6). The first method was used to provide better comparison with the classical localities in the Alps (Allaz et al. 2005). The second incorporates adjustment for the higher Mn contents in garnet and for $\mathrm{Ti}$ and $\mathrm{Al}^{\mathrm{VI}}$ in biotite.

The kyanite-quartz segregations are bordered by biotite selvages. The fact that the biotite $\left(\mathrm{Bt}_{2}\right)$ in them is enriched in Ti enables use of the geothermometric calibration based on the Ti content in biotite proposed by Henry et al. (2005). The temperatures yielded lie in the range $579-639^{\circ} \mathrm{C}$ (Table 4, Fig. 6). The chlorite growing locally at the expence of biotite is evidence of retrogression. The Cathelineau and Nieva (1985) and Ruggieri (2010) calibrations provide temperature estimates of $300-400^{\circ} \mathrm{C}$ and $280-320^{\circ} \mathrm{C}$, respectively, for the chloritisation.

Muscovite overgrowths and submicroscopic muscovite crystals occur along cleavage plains and cracks in kyanite. Fibrolitic sillimanite (Fig. 3c, 4b) and K-feldspar are seen to have replaced that muscovite according to the reaction $\mathrm{Ms}+\mathrm{Qtz} \rightarrow \mathrm{Sil}+\mathrm{Kfs}+\mathrm{H}_{2} \mathrm{O}$.

\subsection{Trace elements and kyanite luminescence}

Trace elements influence kyanite color and cause luminescence. Usually, the luminescence color depends on the presence of Ti, Fe, and $\mathrm{Cr}$ (Müller et al. 2011). Ti, Fe, $\mathrm{Cr}$ and $\mathrm{Mn}$ ions usually substitute for $\mathrm{Al}$ in structurally different positions. $\mathrm{V}$ may replace $\mathrm{Al}$ if it is in a higher oxidation state $\left(\mathrm{V}^{5+}\right.$; Gaft et al. 2012; Neiva 1984).

Twenty four analysis revealed the presence of the following trace elements in the kyanite: ${ }^{23} \mathrm{Na},{ }^{24} \mathrm{Mg},{ }^{39} \mathrm{~K},{ }^{44} \mathrm{Ca},{ }^{47} \mathrm{Ti},{ }^{51} \mathrm{~V},{ }^{52} \mathrm{Cr},{ }^{55} \mathrm{Mn},{ }^{56} \mathrm{Fe}$ (Table 6). The mineral contains significant amounts of $\mathrm{Fe}, \mathrm{Cr}$, Ti and $\mathrm{V}$. Mn and Ti are positively correlated $\left(\mathrm{r}^{2}=0.857\right)$. A strong positive correlation of Fe and Ti is seen where Ti content is low $\left(<90 \mathrm{ppm} ; \mathrm{r}^{2}=\right.$ $0.821)$. Iron is also positively correlated with $\mathrm{Cr}\left(\mathrm{r}^{2}=0.724\right)$ and $\mathrm{V}\left(\mathrm{r}^{2}=0.864\right)$. V substitution in the $\mathrm{Al}$ position is possible only for $\mathrm{V}^{5+}$; its ionic radius (59 $\AA$ ) most closely compares with that of $\mathrm{Al}^{3+}$ (Pearson, Shaw 1960). Both $\mathrm{Cr}$ and $\mathrm{V}$ substitutions cause the pinkish-violet-blue luminescence of the analysed kyanite (Fig. 7).

\subsection{Whole-rock chemical composition}

For this study, the kyanite-quartz segregation (Seg), selvage (Selv) and mylonitised host-rock (garnet-bearing gneiss) were analysed for major and trace elements. Silica content in the kyanite-quartz segregation and in the surrounding gneiss is high whereas that of aluminium is moderate (Table 7). In the selvage, the aluminium content is the highest, 


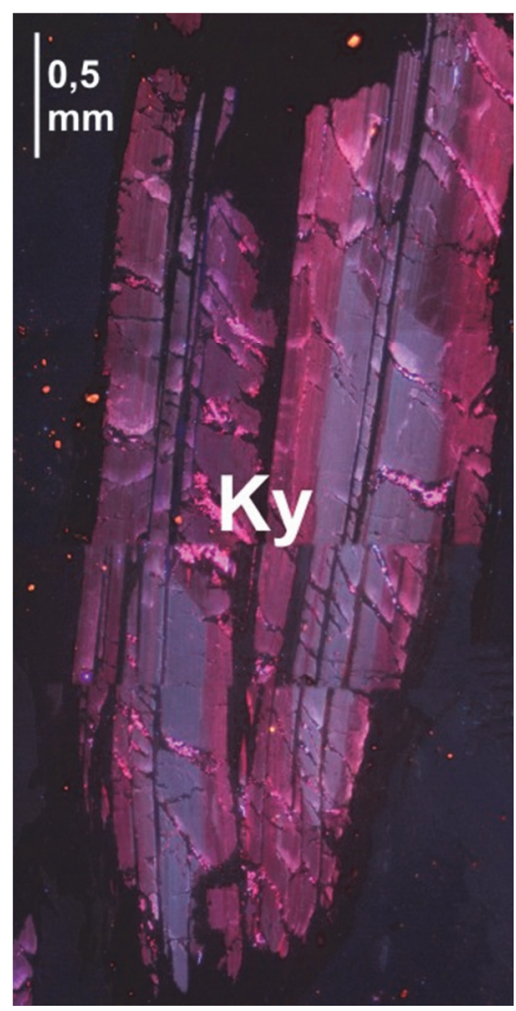

Fig. 7. Cathodoluminescence image of kyanite crystal.

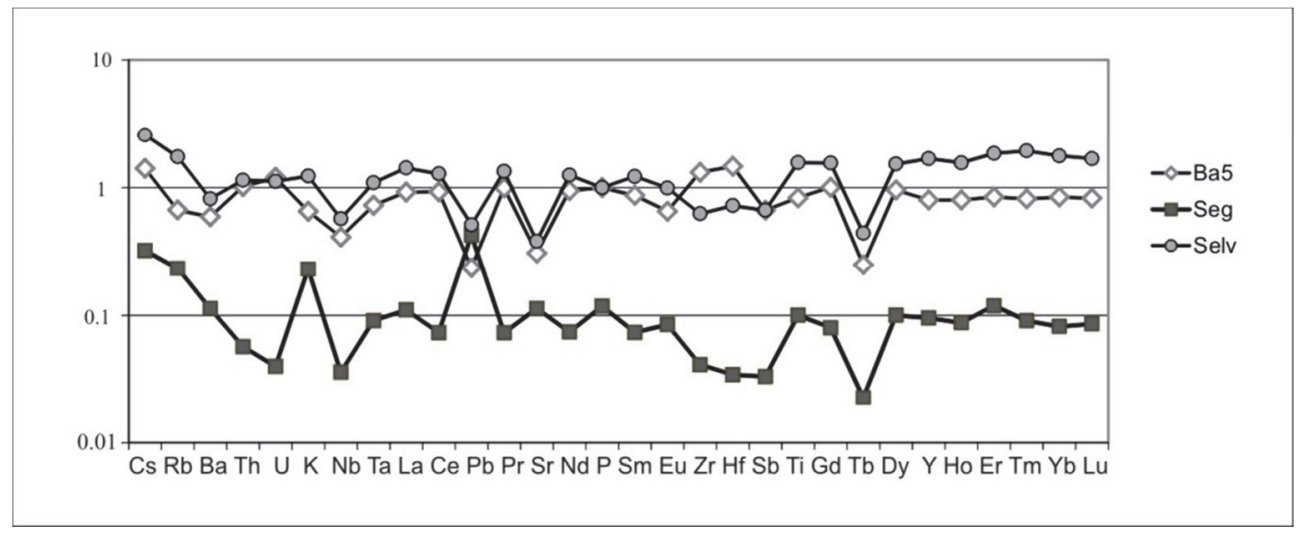

Fig. 8. Trace-element spider diagrams for gneiss (Ba5), kyanite-quartz segregation (Seg) and selvage (Selv). Normalized to continental upper crust (Taylor, Mc Lennan 1981)

due to the abundant presence of Al-rich biotite, almandine garnet, fibrolite, kyanite remnants and secondary muscovite (Fig. 4). The high iron content in the selvage reflects the concentrations of biotite ( $\# f m=0.506-0.551$; Table 4) and almandine garnet (Table 3). 
HFSE elements are more concentrated in the selvage than in the gneiss (Fig. 8) whereas, excepting $\mathrm{Cr}$, they are impoverished in the kyanite-quartz segregations (Table 7; Fig. 8). Chondrite (C1)-normalized rare-earth element (REE) patterns for the selvage, in their similar ranges of REE fractionations and their Eu anomalies (Fig. 9), mirror those of the gneiss. The kyanite segregation has the lowest REE content and a REE fractionation pattern similar to that of the gneiss, except for a nearly absent Eu anomaly ( $\mathrm{Eu} / \mathrm{Eu}^{*}=0.95$; Fig. 9).

TABLE 6

Trace elements in kyanite (in ppm).

\begin{tabular}{llllllllll}
\hline & $\mathrm{Na}$ & $\mathrm{Mg}$ & $\mathrm{K}$ & $\mathrm{Ca}$ & $\mathrm{Ti}$ & $\mathrm{V}$ & $\mathrm{Cr}$ & $\mathrm{Mn}$ & $\mathrm{Fe}$ \\
\hline LoD & 14.3 & 0.9 & 8.3 & 1.7 & 1.2 & 0.01 & 0.01 & 0.1 & 1.1 \\
$\mathrm{Ky} 1$ & 58.2 & 114.2 & 74.9 & 158.2 & 95.8 & 100.9 & 107.0 & 5.1 & 1290.6 \\
$\mathrm{Ky2}$ & - & 87.1 & 59.2 & 112.7 & 90.1 & 106.1 & 98.8 & 2.2 & 1334.2 \\
$\mathrm{Ky3}$ & - & 79.6 & 71.4 & 112.6 & 100.5 & 99.1 & 117.9 & 5.1 & 1432.5 \\
Ky4 & - & 103.8 & 85.1 & 96.1 & 104.1 & 100.2 & 110.3 & 7.5 & 1510.6 \\
Ky5 & - & 81.4 & - & 24.7 & 16.3 & 83.9 & 80.3 & 0.0 & 998.0 \\
Ky6 & 73.9 & 84.5 & 149.1 & 300.6 & 17.4 & 100.0 & 87.9 & 1.3 & 1061.0 \\
Ky7 & 91.1 & 117.8 & 206.4 & 138.7 & 56.8 & 119.8 & 98.4 & 2.3 & 1653.2 \\
Ky8 & 93.6 & 104.3 & 216.0 & 132.1 & 26.2 & 99.6 & 114.6 & 1.5 & 1170.0 \\
Ky9 & 50.3 & 104.7 & 460.1 & 232.8 & 37.5 & 129.1 & 87.4 & 4.1 & 1490.9 \\
Ky10 & 61.2 & 90.0 & 169.6 & 84.4 & 41.4 & 110.4 & 125.7 & 1.5 & 1363.5 \\
Ky11 & 30.1 & 80.9 & 174.9 & 108.4 & 26.1 & 106.8 & 97.0 & 3.8 & 1184.9 \\
Ky12 & 43.2 & 77.8 & 20.3 & - & 23.3 & 94.3 & 139.9 & 0.0 & 1095.0 \\
Ky13 & 35.4 & 89.1 & 22.5 & - & 46.9 & 125.7 & 123.3 & 1.5 & 1228.1 \\
Ky14 & - & 93.3 & 35.9 & - & 32.3 & 96.6 & 95.9 & 1.4 & 1082.4 \\
Ky15 & 139.6 & 83.1 & 233.9 & 124.6 & 32.0 & 102.2 & 128.3 & 2.4 & 1119.0 \\
Ky16 & 34.0 & 63.2 & 88.8 & 113.3 & 28.4 & 95.9 & 114.2 & 1.0 & 984.3 \\
Ky17 & - & 138.3 & 20.1 & 4.5 & 48.0 & 146.4 & 121.0 & 1.8 & 1591.3 \\
Ky18 & - & 124.9 & 26.4 & 47.4 & 56.9 & 157.6 & 151.9 & 1.1 & 1590.1 \\
Ky19 & - & 129.1 & 41.6 & 17.2 & 58.9 & 134.0 & 121.0 & 0.8 & 1427.6 \\
Ky20 & 136.2 & 141.4 & 310.4 & 361.6 & 64.6 & 135.2 & 145.2 & 4.4 & 1692.9 \\
Ky21 & - & 131.5 & - & 66.1 & 86.8 & 135.3 & 109.6 & 1.9 & 1477.3 \\
Ky22 & - & 104.5 & - & 45.8 & 105.7 & 113.5 & 95.1 & 1.5 & 1219.2 \\
Ky23 & 75.7 & 115.9 & 132.4 & 185.5 & 66.9 & 160.2 & 158.2 & 2.8 & 1645.1 \\
Ky24 & 22.2 & 190.5 & 149.1 & 73.7 & 64.4 & 154.3 & 163.4 & 3.2 & 1691.9 \\
\hline LoD - limits of detection. & & & & & & & \\
& & & & & & & & &
\end{tabular}


TABLE 7

Major- and trace-elements composition of kyanite-quartz segregation (Seg), selvage (Selv) and garnet-bearing gneiss (Ba5). Oxides in wt $\%$, trace elements in ppm.

\begin{tabular}{|c|c|c|c|c|}
\hline Sample & LoD & $\mathrm{Ba} 5$ & Seg & Selv \\
\hline $\mathrm{SiO}_{2}$ & 0.01 & 77.6 & 87.2 & 54.9 \\
\hline $\mathrm{TiO}_{2}$ & 0.01 & 0.50 & 0.06 & 0.94 \\
\hline $\mathrm{Al}_{2} \mathrm{O}_{3}$ & 0.01 & 11.19 & 9.69 & 23.22 \\
\hline $\mathrm{Fe}_{2} \mathrm{O}_{3}$ & 0.04 & 2.96 & 0.82 & 8.45 \\
\hline $\mathrm{MnO}$ & 0.01 & 0.03 & 0.01 & 0.08 \\
\hline $\mathrm{MgO}$ & 0.01 & 1.12 & 0.22 & 3.58 \\
\hline $\mathrm{CaO}$ & 0.01 & 0.51 & 0.11 & 0.64 \\
\hline $\mathrm{Na}_{2} \mathrm{O}$ & 0.01 & 1.83 & 0.26 & 0.98 \\
\hline $\mathrm{K}_{2} \mathrm{O}$ & 0.01 & 2.16 & 0.76 & 4.06 \\
\hline $\mathrm{P}_{2} \mathrm{O}_{5}$ & 0.01 & 0.17 & 0.02 & 0.17 \\
\hline LOI & 0.01 & 2.00 & 0.80 & 2.70 \\
\hline Total & & 100.03 & 99.99 & 99.72 \\
\hline $\mathrm{Sr}$ & 0.5 & 102.90 & 37.70 & 127.00 \\
\hline $\mathrm{Ba}$ & 0.1 & 415.00 & 79.00 & 573.00 \\
\hline $\mathrm{Rb}$ & 0.1 & 73.70 & 25.70 & 191.50 \\
\hline Th & 0.2 & 10.70 & 0.60 & 12.00 \\
\hline U & 0.1 & 3.00 & 0.10 & 2.80 \\
\hline $\mathrm{Zn}$ & 0.1 & 33.00 & 15.00 & 89.00 \\
\hline $\mathrm{Pb}$ & 0.1 & 3.50 & 6.30 & 7.60 \\
\hline $\mathrm{Ga}$ & 0.5 & 12.60 & 5.80 & 27.00 \\
\hline $\mathrm{Cr}$ & 20 & 95.80 & 130.00 & 116.30 \\
\hline V & 8.0 & 49.00 & 28.00 & 138.00 \\
\hline $\mathrm{Zr}$ & 0.1 & 316.00 & 9.90 & 150.20 \\
\hline $\mathrm{Hf}$ & 0.1 & 8.50 & 0.20 & 4.20 \\
\hline Y & 0.1 & 17.60 & 2.10 & 37.10 \\
\hline $\mathrm{La}$ & 0.1 & 27.70 & 3.30 & 42.70 \\
\hline $\mathrm{Ce}$ & 0.1 & 55.70 & 4.40 & 76.90 \\
\hline $\operatorname{Pr}$ & 0.02 & 6.67 & 0.49 & 8.98 \\
\hline $\mathrm{Nd}$ & 0.3 & 25.60 & 2.00 & 33.80 \\
\hline $\mathrm{Sm}$ & 0.05 & 4.61 & 0.39 & 6.48 \\
\hline $\mathrm{Eu}$ & 0.02 & 0.85 & 0.11 & 1.29 \\
\hline Gd & 0.05 & 4.02 & 0.32 & 6.22 \\
\hline $\mathrm{Tb}$ & 0.01 & 0.55 & 0.05 & 0.97 \\
\hline Dy & 0.05 & 3.64 & 0.38 & 5.81 \\
\hline Ho & 0.02 & 0.64 & 0.07 & 1.25 \\
\hline $\mathrm{Er}$ & 0.03 & 1.78 & 0.25 & 3.89 \\
\hline $\mathrm{Tm}$ & 0.01 & 0.27 & 0.03 & 0.64 \\
\hline $\mathrm{Yb}$ & 0.05 & 1.86 & 0.18 & 3.90 \\
\hline $\mathrm{Lu}$ & 0.01 & 0.29 & 0.03 & 0.59 \\
\hline
\end{tabular}




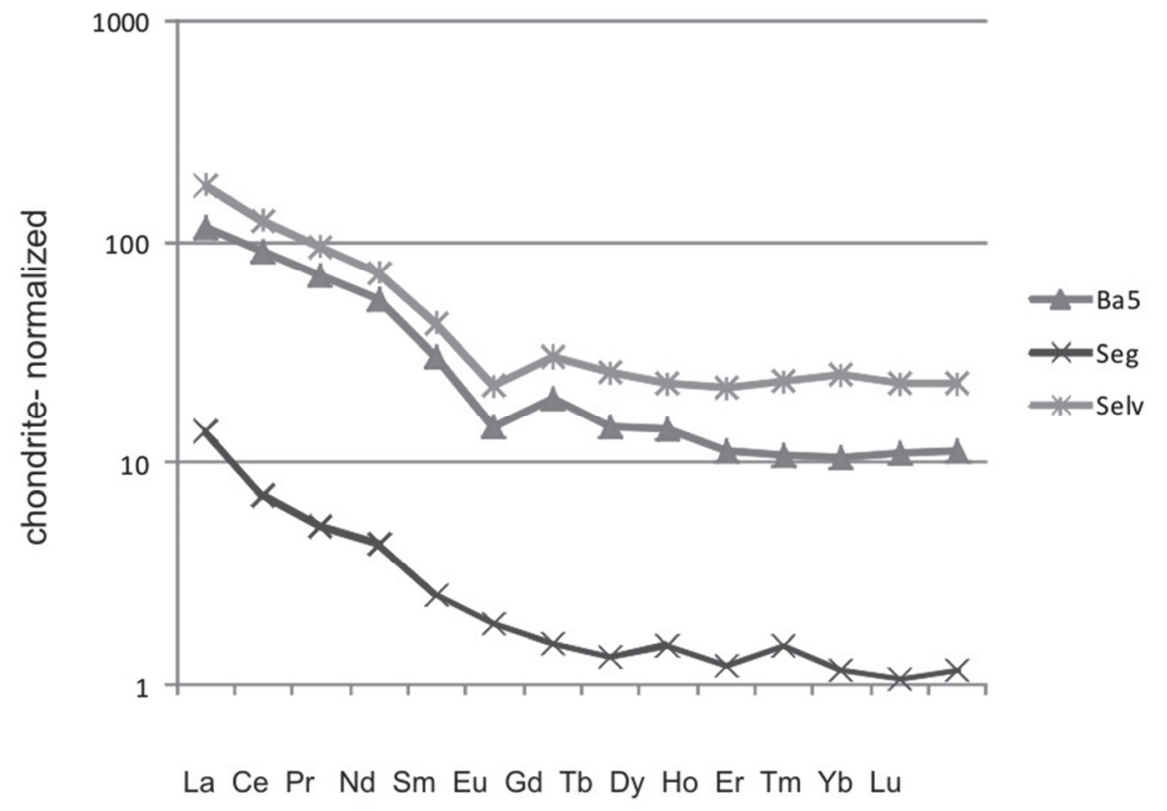

Fig. 9. Chondrite-normalized REE patterns for gneiss (Ba5), kyanite-quartz segregation (Seg) and selvage (Selv) (Sun, McDonough 1989).

\section{Discussion}

\subsection{Phase relations and decompression conditions}

The rutile + almandine assemblage occurring as inclusions and replaced by kyanite + ilmenite + quartz has been deemed to be the result of a pressure drop from $>9$ kbar. The lack of andalusite indicates a pressure above 4 kbar (Pyka et al. 2013a, b; Spear 1993; Yardley 1989). This is in agreement with the earlier P-T reconstructions for the rocks of the area. Janák et al. (1996, 2001) estimated metamprphic conditions in the Upper Unit at 670$700^{\circ} \mathrm{C}$ and 10-15 kbar with marked decompression at 4-5 kbar. Moussalam et al. (2012) documented a decompression path from 16 to $8 \mathrm{kbars}$ and a post-intrusive cooling rate of $\sim 30^{\circ} \mathrm{C} / \mathrm{Ma}$. These results are also consistent with the decompression history from 9-7.5 kbar documented for the northern part of the metamorphic complex (Burda, Gawęda 1999; Burda, Gawęda 2009).

The temperature range computed based on the garnet-biotite geothermometry (432$492^{\circ} \mathrm{C}$ and $507-530^{\circ} \mathrm{C}$; Fig. 6) is similar to that obtained by Allaz et al. (2005) for similar kyanite-quartz veins in the Central Alps and by Whitney (2002) for kyanite-andalusitesillimanite-quartz segregations in the metapelitic Sivrihisar Formation in Turkey. Temperatures of $579-639^{\circ} \mathrm{C}$ computed from $\mathrm{Ti}$ content in low-to-medium pressure metapelitic biotites (Fig. 6) by Henry et al. (2005) are close to those obtained by Janák et al. $(1996,2001)$ from the Tatras. However, it is worth noting that the composition of biotite in 
metapelites may be quite easily reset by heat from, e.g. a granite intrusion (Lavaure, Sawyer 2011) as is the case in the Tatra Mountains metamorphic rocks (Gawęda 2009). Thus, the Ti-biotite temperatures reported here might be alternatively interpreted as reflecting cooling after decompression and re-heating (Gawęda 2009).

The temperatures of biotite chloritization, estimated using the Cathelineau and Nieva (1985) and Ruggieri $(2010)$ calibrations as $300-400^{\circ} \mathrm{C}$ and $280-320^{\circ} \mathrm{C}$, respectively, are similar (within cumulative errors) to those obtained from the granitoid (Gawęda, Włodyka 2012), and represent the retrogression path for the metapelitic rocks of Baranèc Mt.

\subsection{Formation of kyanite-quartz segregations}

Two-step major-element mass-balance calculations were performed. In the first step, the percentages of minerals participating in the segregations were established by modal analysis (Table 8 a). Predominant quartz $(79 \%)$ is accompanied by kyanite $(8 \%)$, muscovite $(12 \%)$ and plagioclase (1\%). That composition was used for the next step of modelling to assess the mobility of major elements, following the method used for mass balance calculations (e.g. Olsen 1984; Burda,Gawęda 1997). As the measured proportion of biotiterich selvage in relation to the whole segregation volume was about $11 \%$, the volume proportion (11:89) was used as a default. The resulting mass-balance calculations (Table $8 b)$ reveal that the Al content was almost stable in the selvage + segregation system whereas the other elements were mobilized. $\mathrm{SiO}_{2}$ mobility was especially remarkable $(83 \%)$ as is reflected in the predominance of quartz in the segregation (Tables 7, 8b). Thus, $\mathrm{SiO}_{2}$, together with other mobile elements such as $\mathrm{Fe}, \mathrm{Na}$ and $\mathrm{K}$ are responsible for the

TABLE 8a

Modal composition of the kyanite-quartz segregation compared to computed composition based on major-element chemistry for segregation $\left(\mathrm{S}_{\mathrm{N}}\right)$, surrounding rocks $(\mathrm{Ba5})$ and selvage (Selv); $\mathrm{S}_{\mathrm{C}}-$ chemistry of the calculated segregations; balance $(B)=S_{C}-S_{N}$.

\begin{tabular}{|c|c|c|c|c|c|c|c|c|c|c|c|}
\hline & Ky & Qtz & $\mathrm{Bt}$ & Ms & $\mathrm{Pl}$ & $\mathrm{Ba} 5$ & $\mathrm{~S}_{\mathrm{N}}$ & Selv & $\mathrm{S}_{\mathrm{C}}$ & B & $\mathrm{B}^{2}$ \\
\hline $\mathrm{SiO}_{2}$ & 37.21 & 100 & 35.62 & 46.7 & 63.54 & 79.1 & 87.95 & 56.6 & 88.22 & -0.3 & 0.071 \\
\hline $\mathrm{TiO}_{2}$ & & & 1.98 & 0.1 & 0 & 0.51 & 0.06 & 0.97 & 0.012 & 0.05 & 0.002 \\
\hline $\mathrm{Al}_{2} \mathrm{O}_{3}$ & 62.63 & & 19.11 & 36.84 & 22.9 & 11.41 & 9.77 & 23.93 & 9.660 & 0.1 & 0.012 \\
\hline $\mathrm{Fe}_{2} \mathrm{O}_{3}$ & 0.16 & & 19.94 & 0.62 & 0 & 3.02 & 0.83 & 8.71 & 0.087 & 0.7 & 0.552 \\
\hline $\mathrm{MnO}$ & & & 0.11 & & 0 & 0.03 & 0.01 & 0.08 & 0 & 0.0 & 0.000 \\
\hline $\mathrm{MgO}$ & & & 9.73 & 0.4 & 0 & 1.14 & 0.22 & 3.69 & 0.048 & 0.2 & 0.029 \\
\hline $\mathrm{CaO}$ & & & 0 & & 4.22 & 0.52 & 0.11 & 0.66 & 0.042 & 0.1 & 0.005 \\
\hline $\mathrm{Na}_{2} \mathrm{O}$ & & & 0.17 & 1.46 & 9.25 & 1.87 & 0.26 & 1.01 & 0.268 & 0.0 & 0.000 \\
\hline $\mathrm{K}_{2} \mathrm{O}$ & & & 9.08 & 9.55 & 0.11 & 2.20 & 0.77 & 4.18 & 1.147 & -0.4 & 0.142 \\
\hline $\mathrm{P}_{2} \mathrm{O}_{5}$ & & & 0 & & 0 & 0.17 & 0.02 & 0.18 & 0 & 0.0 & 0.000 \\
\hline Total & 100.0 & 100.0 & 99.7 & 100.1 & 100.0 & 99.99 & 100.0 & 100.0 & 99.48 & & 0.814 \\
\hline MSWD & & & & & & & & & & & 0.902 \\
\hline
\end{tabular}

116 
Mass balance calculation assuming volume proportion of selvage (Selv) to the segregation $\left(\mathrm{S}_{\mathrm{N}}\right)$ is 11:89; all values are in $w t \%$.

\begin{tabular}{lllllll}
\hline & $\%$ Selv & $\% \mathrm{~S}$ & $\mathrm{Sum}$ & $\mathrm{Ba} 5$ & Balance & $\mathrm{B}^{2}$ \\
\hline $\mathrm{SiO}_{2}$ & 6.2249 & 78.2755 & 84.5004 & 79.1 & 5.4 & 28.949 \\
$\mathrm{TiO}_{2}$ & 0.1067 & 0.0534 & 0.1601 & 0.51 & -0.3 & 0.122 \\
$\mathrm{Al}_{2} \mathrm{O}_{3}$ & 2.6323 & 8.6953 & 11.3276 & 11.41 & -0.082 & 0.007 \\
$\mathrm{Fe}_{2} \mathrm{O}_{3}$ & 0.9581 & 0.7387 & 1.6968 & 3.02 & -1.3 & 1.751 \\
$\mathrm{MnO}$ & 0.0088 & 0.0089 & 0.0177 & 0.03 & 0.0 & 0.000 \\
$\mathrm{MgO}$ & 0.4059 & 0.1958 & 0.6017 & 1.14 & -0.5 & 0.290 \\
$\mathrm{CaO}$ & 0.0726 & 0.0979 & 0.1705 & 0.52 & -0.3 & 0.122 \\
$\mathrm{Na} 2 \mathrm{O}$ & 0.1111 & 0.2314 & 0.3425 & 1.87 & -1.5 & 2.333 \\
$\mathrm{~K}_{2} \mathrm{O}$ & 0.4598 & 0.6853 & 1.1451 & 2.20 & -1.1 & 1.113 \\
$\mathrm{P}_{2} \mathrm{O}_{5}$ & 0.0198 & 0.0178 & 0.0376 & 0.17 & -0.1 & 0.017 \\
& & & & & & 34.704
\end{tabular}

MSWD 5.891

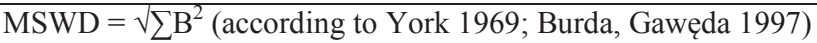

relatively high $\sqrt{M S W D}$ value (5.89; Table $8 \mathrm{~b}$ ), implying that the analysed chemical system was open. However, all elements showing high degrees of change $(\mathrm{Si}, \mathrm{Fe}, \mathrm{Na}, \mathrm{K})$ are generally considered as quite easy to mobilize during metamorphism. $\mathrm{Cr}^{3+}$ shows similar behaviour to $\mathrm{Fe}^{3+}$ and $\mathrm{V}^{5+}$ suggesting that all three migrated together, resulting in the kyanite luminescence (Fig. 7). That could be interpreted as a result of high oxygen fugacity at the segregation-forming stage enabling the incorporation of $\mathrm{Cr}^{3+}$ and $\mathrm{V}^{5+}$ into the kyanite structure. The aluminium remains stable, suggesting that the diffusion, and the associated mass transfer, was limited. As it was mentioned in paragraph 4.3, the kyanite-quartz segregations have the lowest (ten times lower) REE content (Fig. 8, 9). It is caused by the fact that kyanite and quartz do not accumulate REE.

The observations mentioned above and in paragraph 5.1 favour a HP origin for veins, as proposed elsewhere by Widmer and Thompson (2001). The dissolution, transport and reprecipitation of mineral phases (in small fissures growing in response to local pressure gradients) caused local mass transfer due to the migration of fluid released by mineral dehydration. We conclude that the kyanite-quartz segregations were formed in a similar way, with mobilization of fluids during decompression of the Tatra Massif, playing the most important role in the process (stage I in Fig. 6).

After the kyanite-quartz segregations formed, the growth of sillimatite and biotite recrystallization was promoted by heat from the granitoid intrusion (stage II in Fig. 6). Fluids circulating during post-orgenic cooling caused the secondary alterations, i.e. the growth of secondary muscovite and chlorite. 


\section{Conclusions}

1. Kyanite-quartz segregations in metapelites in the Tatra Mountains were formed as a result of the activity of fluids of local origin, characterized by high oxygen fugacity and generated during dehydration of the metapelitic rocks during uplift. The main mechanism was likely diffusion-driven mass-transfer to extension-related cracks and fissures.

2. Heating and further decompression during Variscan granitoid intrusion led to the formation of sillimanite at $579-639^{\circ} \mathrm{C}$ as the pressure dropped to $5-4 \mathrm{kbars}$. The further cooling path was concordant with the general trend for the entire Tatra Massif.

\section{Acknowledgements}

Piotr Dzierżanowski PhD and Mrs Lidia Jeżak are thanked for their help during the microprobe work. The authors benefitted from discussions on trace-element interpretation with prof. Maria Czaja. This study was financially supported by National Science Centre (NCN) grant 2012/07/B/ST10/ 04366 (to Aleksandra Gawęda). Acknowledgements to Padhraig Kennan for English corrections and to Reviwers who contributed to improvement of the paper.

\section{References}

Allaz, J., Maeder, X., Vannay, J.C., \& Steck, A. (2005). Formation of aluminosilicate-bearing quartz veins in the Simano nappe (Central Alps): structural, thermobarometric and oxygen isotope constraints. Schweizerische Mineralogische und Petrographische Mitteilungen, 85, 191-214.

Ague, J. J. (2011). Extreme channelization of fluid and the problem of element mobility during Barrovian metamorphism. American Mineralogist, 96, 333-352. DOI: 10.2138/am.2011.3582.

Burda, J., \& Gawęda, A. (1997). Mass-balance calculations in migmatites from the Upper Kościeliska Valley (The Western Tatra Mts., S-Poland). Mineralogia Polonica, 28(1), 53-68.

Burda, J., \& Gawęda, A. (1999). Petrogeneza migmatytów z Górnej części Doliny Kościeliskiej w Tatrach Zachodnich. Archiwum Mineralogiczne, 52(2), 163-194.

Burda, J., \& Gawęda, A. (2009). Shear-influenced partial melting in the Western Tatra metamorphic complex: Geochemistry and geochronology. Lithos, 110, 373-385. DOI: 10.1016/j.lithos.2009.01.010.

Burda, J., Gawęda, A., \& Klötzil, U. (2011). Magma hybridization in the Western Tatra Mts. granitoid intrusion (S-Poland, Western Carpathians). Mineralogy and Petrology, 103, 19-36. DOI 10.1007/s00710-011-0150-1.

Burda, J., Gawęda, A., \& Klötzil, U. (2013). U-Pb zircon age of the youngest magmatic activity in the High Tatra granites (Central Western Carpathians). Geochronometria, 40(2), 134-144. DOI 10.2478/s13386-013-0106-9.

Cathelineau, M., \& Nieva, D. (1985). A chlorite solid solution geothermometer the Los Azufres (Mexico) geothermal system. Mineralogy and Petrology, 91, 235-244.

Deditius, A. (2004). Petrology and isotopic age of the muscovite blasthesis from the mylonitic zones in the crystalline rocks of the Western Tatra Mountains). Geologia 16. University of Silesia publishing House (in Polish, English abstract).

Ferry, J. M., \& Spear, F. S. (1978). Experimental calibration of the partitioning of Fe and Mg between biotite and garnet. Mineralogy and Petrology, 66, 113-117.

Gaft, M., Strek, W., Nagli, L., Panczer, G., Rossma, G.R., \& Marciniak, L. (2012). Laser-induced time-resolve luminescence of natural sillimanite $\mathrm{Al}_{2} \mathrm{SiO}_{5}$ and synthetic $\mathrm{Al}_{2} \mathrm{SiO}_{5}$ activated by chromium. Journal of luminescence, 132, 2855-2862. DOI 10.1016/j.jlumin.2012.04.045.

Gawęda, A. (2009). Enklawy w granicie Tatr Wysokich (ed.3). Katowice: Wydawnictwo Uniwersytetu Śląskiego.

Gawęda, A., \& Burda, J. (2004). Ewolucja metamorfizmu i deformacji w kompleksie krystalicznym Tatr Zachodnich. Geologia, 16, 153-185. 
Gawęda, A., \& Włodyka, R. (2012). The origin of post magmatic Ca-Al minerals in granite- diorite mingling zones: the Tatra granitoid intrusions, Western Carpathians. Neues Jahrbuch für Mineralogie-Abhandlungen, 190(1), 29-47. DOI 10.1127/0077-7757/2012/0228.

Gawęda, A., \& Kozłowski, K. (1998). Magmatic and metamorphic evolution of the Polish part of the Western Tatra crystalline basement (S-Poland, W-Carpathians). XVI Congress of CBGA, Wienna, 117.

Gawęda, A., \& Golonka, J. (2011). Variscan plate dynamics in the circum- Carpathian area. Geodynamica Acta, 24, 141-155. DOI: 10.3166/ga.24.141-155.

Gawęda, A., \& Szopa, K. (2011). The origin of magmatic layering in the High Tatra granite, Central Western Carpathians - implications for the formation of granitoid plutons. Transactions of the Royal Society of Edinburgh Earth Sciences, 102, 1-16. DOI 10.1017/S1755691012010146.

Gorek, A. (1956). Geologicka Stavba Zapadnych Tatier. Geologický Sbornik Slovenske Akadémie Vied. Bratislava, VII.

Gorek, A. (1969). Postavenie zvyskov metamorfovaneho plasta v granitoidnom masive Vysokych Tatier a ich vztah v Zapadnych Tatrach. Geologica, 4, 103-115.

Henry, D. J., Guidotti, Ch., \& Thomson, J. A. (2005). The Ti-saturation surface for low-to-medium pressure metapelitic biotites: Implications for geothermometry and Ti-substitution mechanisms. American Mineralogist, 90, 316-328. DOI: 10.2138/am.2005.1498.

Indares, A., \& Martignole, J. (1985). Biotite- garnet geotermometry in the granulite facies: the influence of Ti and $\mathrm{Al}$ in biotite. American Mineralogist, 70, 272-278.

Janák, M., O`Brien, J. P., Hurai, V., \& Reutel, C. (1996). Metamorphic evolution and fluid composition of garnetclinopyroxene amphibolites from the Tatras Mountains, Western Carpathians. Lithos, 39, 57-79.

Janák, M., Plasienka, D., \& Petrik, I. (2001). Extrusion to the Tatra Mountains, Central Western Carpathians: Tectonometamorphic records of Variscan and Alpine Orogeny. Geolines, 13, 141-148.

Kohút, M., \& Janák, M. (1994). Granitoids of the Tatra Mts., Western Carpathians: Field relations and petrogenetic implications. Geologica Carpathica, 45(5), 301-311.

Lavaure, S., \& Sawyer, E. W. (2011). Source of biotite in the Wuluma Pluton: Replacement of ferromagnesian phases and disaggregation of enclaves and schlieren. Lithos, 125, 757-780. DOI: 10.1016/j.lithos.2011.04.005.

Moussallam, Y., Schneider, D. A., Janák, M., Thoni, M., \& Holm, D. K. (2012). Heterogeneous extrusion and exhumation of deep-crustal Variscan assembly: Geochronology of the Western Tarta Mountains, northen Slovakia. Lithos, 144-145, 88-108. DOI: 10.1016/j.lithos.2012.03.025.

Müller, A., van den Kerhof, A. M., \& Broekmans, M. A. T. M. (2011). Trace element content and optical cathodoluminescence of kyanite. X International Congress for Applied Mineralogy, Trondheim, 453-461. DOI: 10.1007/978-3-642-27682-8_54.

Olsen, S. N. (1984). Mass-balance and mass-transfer in migmatites from the Colorado Front Range. Contribution to Mineralogy and Petrology, 85, 30-44.

Pearson, G. R., \& Shaw, D. M. (1960). Trace elements in kyanite, sillimanite and andalusite. American Mineralogist, 45, 808-817.

Pyka, P., Szopa, K., Gawęda, A., \& Krzykawski, T. (2013a). Kyanite-quartz segregations in the metamorphic complex of the Western Tatra Mountains, Central Western Carpathians. In: Broska, I., \& Tomašových, A. (Eds.): GEEWEC 2013. Geological evolution of the Western Carpathians: new ideas in the field of interregional correlations. Abstract book. Bratislava: Geological Institute, Slovak Academy of Science.

Pyka, P., Szopa, K., \& Gawęda, A. (2013b). Megacrysts of kyanite from Baranèc Mt., Western Tatra Mountains, Slovakia. Mineralogia, 44 (1-2), 35-41. DOI: 10.2478/mipo-2013-0002.

Ruggieri, G., Dallai, L., Nardini, I., Henriquez, E. I., \& Arias, A. (2010). Thermo-chemical variatons of the hydrothermal fuids in the Berlin Geothermal Field (El Salvador). World Geothermal Congress Proceedin, Bali, Indonesia, 1-7.

Spear, F. S. (1993). Metamorphic Phase Equilibria and Pressure-temperature- time paths (ed. 1). Waszyngton: MSA Monograph.

Sun, S. S., \& McDonough, W. F. (1989). Chemical and isotopic systematics of oceanic basalts: implications for mantle composition and processes. In Magmatism in the Ocean Basins. Saunders, A. D. and Norry, M. J. (Editors), Geological Society of London, 42, 313-345. DOI: 10.1144/GSL.SP.1989.042.01.19.

Taylor, S. R., \& McLennan, S. M. (1981). The composition and evolution of the continental crust-Rare Earth Element evidence from sedimentary rocks. Philosophical Transactions of the Royal Society of London, 301(1461), 381-399. 
Whitney, D. L. (2002). Coexisting andalusite, kyanite and sillimanite: Sequential formation of three $\mathrm{Al}_{2} \mathrm{SiO}_{5}$ polymorphs during progressive metamorphism near the triple point, Sivrihisar, Turkey. American Mineralogist, 87, 405-416.

Widmer, T., \&, Thompson, A. B. (2001). Local origin of high pressure vein material in eclogite facies rocks of the Zermatt-Saas Zone, Switzerland. American Journal of Science, 301, 627-656.

Yardley, B. W. D. (1989). An introduction to metamorphic petrology ( $1^{\text {st }}$ edition); Longman Scientific \& Technical. 